\section{Down and Out}

Surprisingly little is known about the drifting, anonymous world of lodging-houses, hostels, and reception centres, or about that ultimate in opting out-“ sleeping rough." A recently published survey ${ }^{1}$ by the National Assistance Board on homeless single persons showed that on 8 December 1965 26,884 men and 1,905 women were living in 550 lodginghouses, hostels, and shelters. Of the men $59 \%$ had lived in lodging-houses for five or more years; $40 \%$ had been out of touch with all relatives for more than a year; $20 \%$ were not registered with a doctor ; and $37 \%$ had not worked for six months or more. At any time about 1,000 people are sleeping rough and almost 1,000 are using reception centres ; the groups overlap, and $28 \%$ of men in lodging-houses sometimes sleep rough. As for the lodging-houses, the fact emerges that $59 \%$ of beds are provided by private owners on a commercial basis, while the Salvation Army provides a further $23 \%$ of places.

Despite some excellent literary descriptions of the homeless man in London-such as by Jack London, ${ }^{2}$ George Orwell, ${ }^{3}$ and B. Breed, ${ }^{4}$ who in a recent book has described the plight of the down-and-out alcoholic-comparatively little has been written about the medical aspects. K. Marsh ${ }^{5}$ reported on the findings of a mass $x$-ray survey carried out in a London reception centre; J. S. Whiteley ${ }^{6}$ discussed the incidence of mental illness in the same population; and previous reports issued by the National Assistance Board ${ }^{7}$ also contain some valuable information.

At p. 1561 of this week's B.M.7. Professor Richard Scott and his colleagues discuss the illnesses found in a group of 310 residents of Edinburgh lodging-houses. The authors are careful to point out that a survey based only on examination of those who come to a general practitioner for help cannot give an estimate of illness in the lodging-house population as a whole. Nevertheless, their preliminary report gives some useful pointers. Thus there was a striking incidence of pulmonary tuberculosis, with $10 \%$ of patients having had this diagnosis made at some time. Mental disorder was found in $12 \%$ of patients, and chronic alcoholism in a further $9 \%$.

Clearly one section of the lodging-house population is using this accommodation for reasons no more abnormal than those that prompt a wealthy bachelor to rent a service flat. The concern must be for the others-those who are homeless for pathological reasons, such as physical infirmity, gross mental illness, or abnormal personality with consequent petty recidivism, alcoholism, or drug addiction. People in this latter category start with one disorder and contract a second disability-institutionalization in homelessness. The best moment for taking action is undoubtedly when the new recruit to homelessness is seen. The challenge is to organize welfare services so that they can cope straight away with the real emergency constituted by each new case. Government and voluntary agencies deserve warm praise for what they are already attempting, but the resources for this sort of work are so inadcquate that we continue more often to lament the chronic case than to treat the acute. Should a hostel service

\footnotetext{
Homeless Single Persons, 1966, Ministry of Pensions and National Insurance. H.M.S.O., London. See also p. 1604.

2 London, J., People of the Abyss, 1903. London. Reprinted in 1962 by Arco, London.

s Orwell, G., Down and Out in Paris and London, 1933, Gollancz, London.

- Breed, B., The Man Outside, 1966, Epworth Press, London.

Marsh, K., Lancet, 1957, 1, 1136.

- Whiteley, J. S., ibid., 1955, 2, 608

Annual Reports of National Assistance Board, 1950-1965, H.M.S.O., London.
}

be planned to try to solve the tangled problems which homelessness sets? Demarcation disputes between Governmen: departments, uncertainty about the fine distinction between "treatment" and "rehabilitation," muddle about loca: authority and central responsibility, confused reduplication o: voluntary effort-all at present delay the chance of progress Indeed, a hostel service might in sheer economic terms be a saving over present haphazard procedures: the total amoun: of National Assistance paid to users of lodging-houses comes alone to about $£ 2 \mathrm{~m}$. a year. And efficient organization is n $\boldsymbol{\theta}^{*}$ the antithesis of human concern.

\section{Thoracic Inlet Tumours}

Though persistent pain in the shoulder and arm is common it is usually due to a relatively benign and treatable condition. Lesions around the shoulder joints and irritation of the cervical nerve roots in association with spondylosis or disc degeneration account for the majority of cases. In some patients, however, pain in the shoulder and arm may be the first symptom of more serious disease, one example of which is the so-called Pancoast or "superior pulmonary sulcus" tumour. In a recent report ${ }^{1}$ from the Mayo Clinic the records of 94 patients seen between 1938 and 1963 were analysed The authors use the term " thoracic inlet tumour," which they prefer to the 14 other names given to this type of tumour in the past. H. K. Pancoast ${ }^{2}$ suggested that the tumour arose from an embryological rest, but it now seems clear that malignant tumours in this region have various origins, the most common being the apex of the lung. Of 35 cases of the Mayo Clinic series where histological review of the sections was possible there were three squamous-cell carcinomas and three mucus-producing adenocarcinomas. while the remainder were high-grade carcinomas which could not be classified as the amount of tissue was too small.

Pain was the first symptom in 86 patients. It was persistent, often severe, and most marked in the region of the shoulder and medial side of the upper arm, at times extending down to the ulnar side of the hand. Some patients also had pain in the front of the upper chest, and patients in whom the tumour had spread to the superior mediastinum developed pain between the shoulder blades.

Thoracic inlet tumours cause abnormal neurological signs in four ways. Firstly, a Horner syndrome was found in $64 \%$ of patients from spread to the inferior cervical sympathetic ganglion. Secondly, the inferior trunk of the brachial plexus, or the eighth cervical and first and second thoracic roots, as they form the inferior trunk, are affected early, giving rise to pain radiating down the medial side of the arm, paraesthesiae. and, later, sensory impairment on the medial aspect of the hand and forearm, together with weakness and wasting of the intrinsic muscles of the hand. Thirdly, the recurrent laryngea! nerves may be affected, when there will be vocal-cord paralysis and hoarseness ; this was noted on the left side in four patients and on the right side in two. Finally, the tumour may invade the spinal canal and compress the spinal cord, giving rise to long-tract signs. In a third of the patients a palpable nodk or mass was found in the supraclavicular or rotroclaviculat region.

\footnotetext{
1 Hepper, N. G. G., Herskovic, T., Witten, D. M., Mulder, D. W., and Woolner, L. B., Ann. intern. Med., 1966, 64, 979. 2 Pancoast, H. K., 尹. Amer. med. Ass., 1924, 83, 1407.

s McGoon, D. C., Ann. Surg., 1964, 159, 407
} 
The diagnosis is most readily confirmed by radiology but in some early cases $x$-ray changes may be absent or minimal. At the Mayo Clinic the $x$-ray films of 47 of the patients were reviewed and $6 \%$ were found to be normal. In an additional $30 \%$ the lesions were of such a size or were so hidden by the confluence of bony shadows that they could easily have been missed. In 34 patients the lesion took the form of a mass at the extreme apex of the lung, often associated with pleural thickening, and in 10 the lesion consisted of gross pleural thickening only. Destruction of bone was seen in 14 cases, in all of which one or more of the first three ribs was affected, and in six the growth had also spread to adjacent vertebral bodies. In any suspicious case tomograms of the apices of the lungs are necessary, together with riews of the vertebrae. Cytological examination of the sputum in 45 patients revealed malignant cells in only 7 , while bronchoscopy done in 10 cases gave negative results except once when carcinoma cells were found in the bronchial secretions. In some cases where the diagnosis was in doubt an extended supraclavicular exploration of the type described by D. C. McGoon ${ }^{3}$ was performed; in this the anterior scalene muscle is transected or retracted and the subclavian artery is retracted to expose the tumour for biopsy. In 9 of the 22 patients in whom simple supraclavicular or scalene node dissection gave negative results the extended operation exposed the tumours.

\section{Facial Paralysis in Hypertension}

The first reaction of most doctors on seeing a hypertensive patient with facial paralysis would probably be to make a diagnosis of stroke. In this instance facial palsy would be of the upper motor neurone type, but there is also a welldocumented association between lower motor neurone facial paralysis and severe hypertension.

Probably the first report of this condition was nearly 100 years ago from Guy's Hospital, when W. Moxon ${ }^{1}$ noted facial palsy shortly before the death of a man of $4 \mathrm{~S}$ who had Bright's disease. Post-mortem examination showed a haemorrhage in the facial canal. A further patient with Bright's disease and facial palsy was reported in Japan in $1900,{ }^{2}$ but neither this patient nor Moxon's had the blood pressure taken, so the presence of hypertension can only be inferred. In 1926 F. H. Redwood ${ }^{3}$ described a girl of 11 with hypertension and papilloedema who developed a left facial palsy before death. At necropsy the brain was somewhat oedematous but there were no focal lesions. N. M. Keith, H. P. Wagener, and J. W. Kernohan, ${ }^{4}$ in their paper on the syndrome of malignant hypertension, included details of two patients with facial palsy in their tabulated data. S. Amberg, ${ }^{5}$ writing on hypertension in the young, described in more

Moxon, W., Trans. path. Soc. Lond., 1869, 20, 420.

Sei-i-Kai med. f., 1900, 19.

s Sei-i-Kai med. F., 1900, 19.

- Kedwood, F. H., Virginia med. Mth., 1926, 53, 103. Wagener, H. P., and Kernohan, J. W., Arch. intern. Med., 1928, 41, 141.

s Amberg, S., Amer. F. Dis. Child., 1929, 37, 335.

" May, E., Bull. Soc. med. Hôp. Paris, 1930, 54, 915

Monier-Vinard, and Puech, P., ibid., 1930, 46, 977.

Merwath, H. R., Ann. intern. Med., 1942, 17, 298.

- Castels, C., An. Fac. Med. Montevideo, 1946, 31, 877.

- Akerman, A Arch. Neuro-psiquiat. (S. Paulo), $1954,12,441$

Lloyd, A. V. C., Jewitt, D. E., and Still, J. D. L1., Arch. Dis. Childh., $1966,41,292$.

Clarke, E., and Murphy, E. A., Brit. med. F., 1956, 2, 1319. detail one of Keith's patients and mentioned a girl of 13 and a boy of 9 with malignant hypertension who developed facial palsy. The information was included in case reports, and Amberg did not suggest that there was any connexion between the facial paralysis and hypertension. E. May in 1930 suggested that chronic nephritis might cause facial palsy and described two men aged 36 and 37 with chronic nephritis, hypertension, and peripheral facial paralysis. Two other Parisian physicians, Monier-Vinard and P. Puech, ${ }^{7}$ described a man of 21 with chronic nephritis, hypertension, and gross papilloedema whose face became paralysed on the right side shortly before death. Post-mortem examination showed a haemorrhage into the facial canal of the petrous bone, similar to that described by Moxon many years before.

Most of these earlier articles concerned facial palsy in children or young adults with very' severe hypertension and usually with papilloedema. There have also been suggestions that it can occur in benign hypertension. H. R. Merwarth ${ }^{8}$ reviewed 468 patients with faciai paralysis seen over 17 years and found that 24 had hypertension. C. Castells ${ }^{9}$ found 13 patients out of 45 with facial palsy who had hypertension. A. Akerman ${ }^{10}$ found 5 patients with hypertension out of 42 examined with facial palsy. Two of these hypertenstves had papilloedema. These reports of facial palsy in benign hypertension do not take into account the prevalonce of hypertension in the general population. Indeed, Merwarth's series contained fewer hypertensives than would have been expected from a purely random association. Now a recent report by A. V. C. Lloyd, D. E. Jewitt, and J. D. Lloyd Still ${ }^{11}$ draws attention to the association between malignant hypertension and lower motor neurone facial paralysis, particularly in children. These authors found 6 cases among 35 children with severe bypertension. E. Clarke and E. A. Murphy ${ }^{12}$ include a reference to the association in their paper on the neurological manifestations of malignant hypertension. It appears that the condition is not confined to children and that the association is a real one.

The cause seems to lie in the widespread arteriolar disease which is a feature of malignant hypertension. This leads to infarction and swelling of, or haemorrhage into, the facial nerve in its bony canal. There are only a few places in the body where damage to a single arteriole causes recognizable symptoms, and it is worth remembering this condition if a child is seen with Bell's palsy.

\section{${ }^{6}$ British Journal of Medical Education"}

Probably more has been written about education for the profession of medicine than for any other occupation. Yet discussion continues to increase-for three main reasons. The first is that medicine itself is changing so fast that the content of what is taught must be continually revised; thus we are now in the era of paperback and loose-leaf textbooks. Secondly, owing to the rapidity of change the need for education to continue throughout professional life is now everywhere recognized. And, thirdly, studies of how best to teach

1 Published quarterly by the British Medical Association, London. Annual subscription $£ 3$ 3s. (abroad £3 10s.; U.S.A. \$10).

2 Brit. med. ₹., 1966, 2, 1442. 